\title{
OCCURRENCE OF DOLIOLIDS AND SALPS DURING 1958, 1959, and 1960 OFF THE SÃO PAULO COAST *
}

\author{
(Received in 26/6/1967) \\ D. Q. Tavares \\ Instituto Oceanográfico da Universidade de São Paulo
}

\begin{abstract}
SYNOPSIS
Plankton samples were collected fortnightly off São Paulo coast during 1958, 1959 and 1960.

The following Thaliacians were recorded Doliolum nationalis, Dolioletta gegenbauri and Thatia democratica. Morphological and ecological aspects of each species were studied.

Doliolids seemed to be endemic in the region, occurring throughout the whole period of survey. The salps occurred only occasionally in dense swarms suggesting that this species is carried into the region by offshore waters.
\end{abstract}

\section{INTRODUCTION}

In this paper an attempt is made to describe some distributional and ecological aspects of the Thaliacea occurring off the coast of São Paulo State.

The group has already been recorded in Brazilian waters by the 'Plankton' (1894). 'Terra Nova' (1933) and 'Meteor' (1939) Expeditions.

The present collection belongs to the Instituto Oceanográfico da Universidade de São Paulo and is registered under "Serie E". It has already been studied by VANNUCCI $(1962 ; 1963)$, BJöRNBERG (1963), Almeida Prado (under press), Forneris (1965). Further research on same is in progress.

The families studied here are Doliolidae and Salpidae. Pyrosomidae was not found in this collection.

\section{MATERIAL AND METHODS}

The samples were collected fortnightly at three fixed stations during 1958, 1959 and 1960 off Cananéia coast and, in 1960, off Santos coast. Both stations are off São Paulo State, Brazil (Fig. 1). These stations will be called Point I, Point II and Point III and abbreviated as: Pt I, Pt II and Pt III. The positions of the stations are the following:

* This research was partially supported by "Fundacão de Amparo à Pesquísa do Estado de São Paulo", Publ. n.o 248 do I.O. da USP.

\section{Cananéia:}

Pt I - 2507.9' lat. S - 47 $7^{\circ} 48.4^{\prime}$ long. W - Local depth: $19 \mathrm{~m}, 5.6 \mathrm{~nm}$ off-shore.

Pt II $-25^{\circ} 08.4$ ' lat. $\mathrm{S}-47^{\circ} 44.2^{\prime}$ long. W - Local depth: $20 \mathrm{~m}, 9.5 \mathrm{~nm}$ off-shore.

Pt III - $25^{\circ} 09.5^{\prime}$ lat. S $-47^{\circ} 35.7^{\prime}$ long. W - Local depth: $30 \mathrm{~m}, 17.2 \mathrm{~nm}$ off-shore.

Santos:

Pt I $-24^{\circ} 04.5^{\prime}$ lat. S $-4^{\circ} 17.7^{\prime}$ long. W - Local depth $27 \mathrm{~m}, 2.5 \mathrm{~nm} \mathrm{SE}$ off Moela Isle.

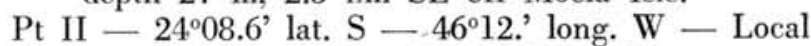
depth $35 \mathrm{~m}, 10 \mathrm{~nm}$ SE off Moela Isle.

Pt III - $24^{\circ} 15.9^{\prime}$ lat. S - 46 $6^{\circ} 07.0^{\prime}$ long. W - Local depth $42 \mathrm{~m}, 20 \mathrm{~nm}$ SE off Moela Isle.

Two hauls were made at each point: a vertical haul with Hensen net and a deep horizontal haul with a Clarke Bumpus sampler. Salinity and temperature were taken simultaneously. The vertical samples were totally counted and are the subject of this paper. For additional information, Clarke Bumpus samples were occasionally counted. The depth of the haul depended on local depth, starting at $3 \mathrm{~m}$ above the bottom to the surface. As a first approximation, it can be assumed that the "cylinder" of water (generated by the vertical displacement of the mouth of the net) was entirely filtered. The figures for each sample counted are expressed in cubic metres. 
All three points at Cananéia were studied but only Pt I and III from Santos. The samples were preserved in $4 \%$ Formalin, for detailed observation, some specimens were stained in Bengal-Rose-pink or Toluidine Blue. The drawings were made by means of a camera lucida.

\section{ENVIRONMENTAL FEATURES OR NOTES}

The continental shelf is very wide in the Southern Brazilian Region, extending over $10 \mathrm{~nm}$ off Santos. The hydrographical condition of this region was studied by Emilsson (1961) and can be summarized as follows:

Above the outer part of the shelf the Tropical Water Mass is found or the Brazil Current which is defined as having a salinity higher than $36 \%$ and temperature higher than $20^{\circ} \mathrm{C}$. Below this mass, flowing northwards, an undercurrent is found, the Sub-Tropical Water, formed near the western extremity of the Sub-tropical Convergence, with temperature varying from 10 to $20^{\circ} \mathrm{C}$, and salinity ranging from $35-36 \%$. Along the middle zone of the continental shelf this Sub-Tropical Water is upwelled and a new water-mass is formed, called the ShelfWater, by Emilsson. It is formed by the mixing of the Sub-Tropical, Tropical and Coastal Waters, and is heated locally by solar radiation.

Along the coast a Coastal Water Mass may be found the extent and salinity of which depend upon the run-off of fresh water, and also upon the intensity of the mixture of the waters further along the coast. In front of the States of Rio de Janeiro, São Paulo and Paraná, the salinity is lower than $35 \%$.

Some details of Cananéia and Santos should be mentioned. The three points studied at Cananéia are situated just off an estuary; the influence of land drainage is therefore still noticeable, mainly at Pt I, the closest to the coast.

Plotting the data in T-S diagram a large predominance of Coastal Water (EMilsson, op. cit,) was observed mainly on the surface at the three points; Shelf-Water made some instrusions at Pt I and II, lying always below the coastal water. At Pt III, the most offshore, a heterogeneous column of coastal water predominated over the shelf water. The tropical water was found only twice as a small layer below the shelf water layer, once in February and once in April, 1960. At Santos a heterogeneous column of coastal water over shelf water occurred at $\mathrm{Pt}$ I. The coastal water decreases gradually towards Pt II and, finally, at Pt III, the shelf-water prevailed. Tropical water was present only nearer to the bottom, from July to November 1960 .

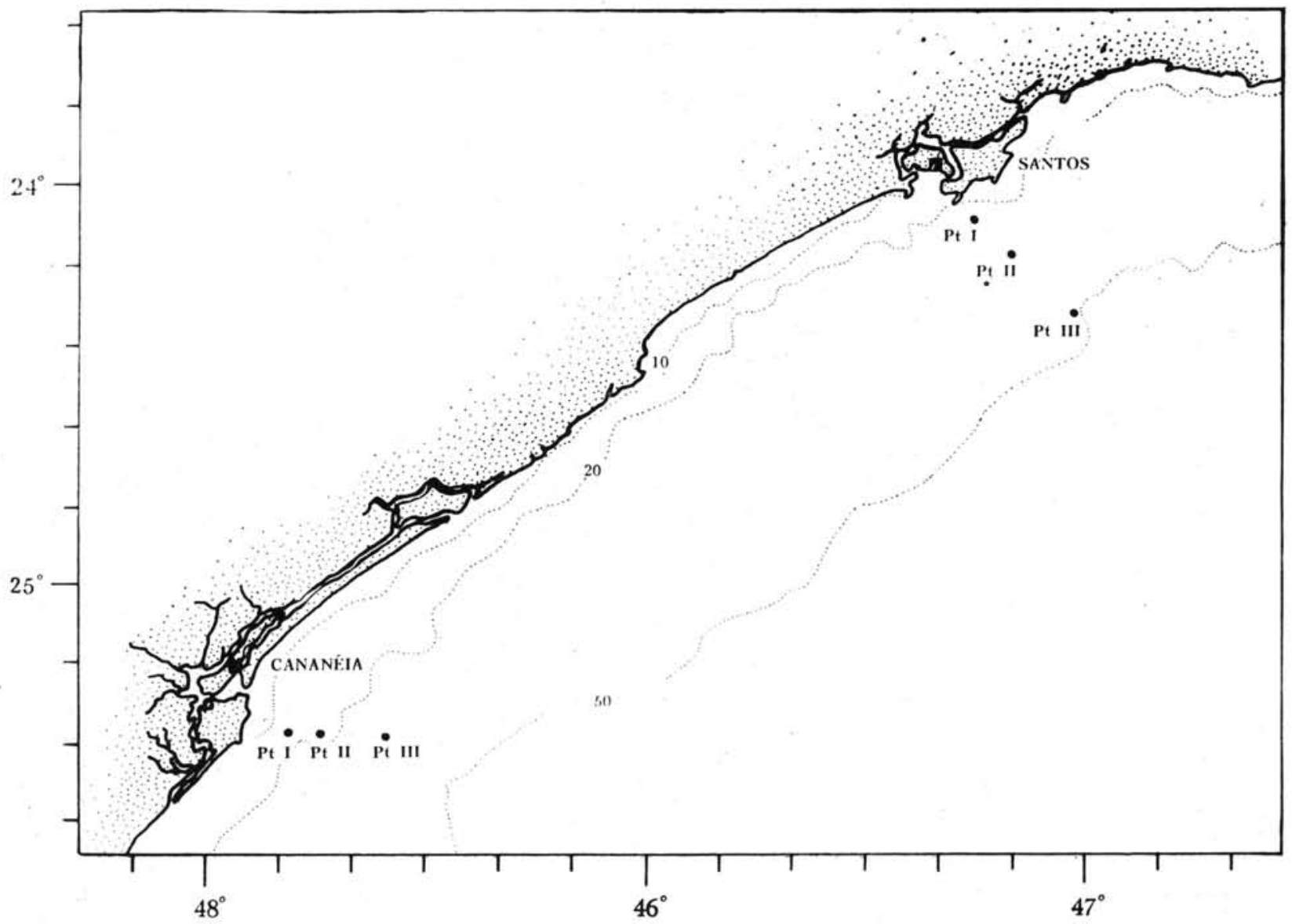

Fig. 1 - Sketch showing the positions of the three fixed stations off Cananéia and Santos coast. 


\section{MORPHOLOGY AND TERMINOLOGY}

Among Tunicates, doliolids have the most complicated alternation of generations which produces several different forms. The oozoid has a sexual origin, passing through a tailed larval stage which gives rise to an adult form that generally produces three kinds of buds (blastozooids):

a) Trophozooids - which remain attached to the oozooid

b) Phorozooids - which are free-swimming and asexual

c) Gonozooids - which in the earliest stages, are carried on the ventral stalk of the phorozooid. As adults, they are free-swimming and hermaphroditic, their ova will develop into oozooids after passing by the larval stage.

On completing the production of buds, the oozooid becomes flaccid, the muscles broad-banded, and there is a total desintegration of the viscera. It is then known as an "old nurse". To identify gonozooids and phorozooids, one must observe the position and length of the endostyle, the arrangement of the alimentary tract, and finally the length and level of the attachment of the gill-lamella. The clearest way to distinguish the gonozooids is by their gonads, and the phorozooids by their ventral stalk.

The oozooid or, the "old-nurse" in its final stage, is easily recognised by its dorsal process to which the earlier buds are attached. Garstang (1933) suggested the analysis of the width and position of the enlarged portion of the muscle-bands as useful characteristics for determination of the species, to which the "old-nurse" belongs.

Only Doliolum nationalis Borgert, 1893 and Dolioletta gegenbauri Uljanin, 1884 were recorded in this material.

D. nationalis (Plate I) is characterised by:

a) the endostyle extending from the second to the fourth ring-muscle.

b) the alimentary tract placed horizontally with a U-shaped intestinal loop turned slightly to the right with the anus opening into the cloacal cavity at the level of the sixth muscle.

c) the gill-lamella (beginning) dorsally on the second muscle and ending vertically at about the fifth.

Larva, oozooid and "old-nurse" of D. nationalis are still unknown. These stages are described only for $D$. denticulatum within the genus Doliolum ss. GoDEAUX (1961) commented that the criteria applied to oozooids at present do not provide the possibility of distinguishing between oozooids of the same genus.

Dolioletta gegenbauri (Plates I, II) has the endostyle extending from just behind the second muscle to near the fifth. The gill-lamella is attached dorsally near the second muscle, below the ganglion and ventrally on the level of the fifth muscle. The alimentary tract is also placed horizontally but the intestine forms a close dextral coil with the anus opening into the cloacal cavity at the seventh inter- space. This classification of the Doliolidae was based on Garstang (1933), Fraser (1947b) and Berrill (1950).

The alternation of generations in the life-history of salps is known to be the same as that of doliolids. The oozooids (called solitary forms) are asexual and produce cha'ns of blastozooids (aggregate forms), budding from a stolon.

The characteristics for specific identification are the number and arrangement of the body musclebands, the position and form of the digestive tract and the shape of the test. There is a great dimorphism between the solitary and aggregate forms.

Only Thalia democratica Forskal, 1775 was recorded. The solitary form of this species has its first, second and third anterior body-muscles close together dorsally; the posterior muscles (fourth and fifth), are just in front of the cloacal opening. Except for the fourth muscles, all the others form a band which is continuous ventrally. The endostyle is situated along the anterior part of the body. The test is rigid and is noticeable because it has two long appendages protruding at the posterior end at both sides; a few other smaller appendages can be found near them.

The aggregate form has the first, second and third body-muscles linked dorsally and the fourth, which divides into two branches is directed posteriorly. All the muscle are interrupted ventrally. The test is smooth and not very rigid. The epidermis and its associated tissues (called mantle) protrude into the test. The digestive tract has a compact "nucleus" shape and, in both forms, is found in a posterior swelling of the body. The determination of the species was based on Metcalf (1918) and Fraser (1947a).

\section{Family: DOLIOLIDAE \\ Genus: Doliolum ss. (Garstang, 1933) \\ Doliolum nationalis Borgert 1893}

This species is usually associated with warm waters. Its presence was noticed in the Atlantic by the 'Plankton' (Borgert, 1894) and 'Meteor' (KRuger, 1939) Expeditions. In the Atlantic Ocean Borgert (l. c.) mentioned the occurrence of phorozooids and gonozooids, and the first in greater abundance. This was also noticed among the present samples: the phorozooids were found in large numbers while gonozooids were only rarely taken. Several authors, including Russell (1933), BerNard (1958) and TERry (1961) studying plankton D. nationalis, also found phorozooids more common than gonozooids.

From a representative number of specimens, the length of the body and of the endostyle was measured, and the number of pairs of gill-slits counted. The gonozooid and phorozooid did not differ significantly $(\mathrm{P}<0.05)$ when taken from the same sample; the averages below therefore apply to both forms:

Total length: $1.74 \mathrm{~mm}$

Endostyle length: $0.68 \mathrm{~mm}$

No. of gill-slit pairs: 19 . 
Distribution: D. nationalis caught at Cananéia and Santos in this period presented a highly irregular pattern of distribution, mainly at $\mathrm{Pt} \mathrm{I}$. VANNUCCI (1962), working on the same material, pointed out the irregularity of the zooplankton standing stock, especially at this point. Since this station is very near to the coast, the same author suggested that the widely varying coastal conditions could affect the pattern of distribution.

The average annual occurrence (Tab. I) shows quantitative predominance at $\mathrm{Pt}$ III, not ratified in 1960 at Cananéia. This can be explained by a delayed increase in number of the $D$. nationalis' population. The outburst of this species normally occurs here in November and December (1958, 1959). In 1960, however, this outburst took place one month later and since the figures for January (1961) fall outside the scope of this study therefore they are not included here in the data for 1960 .

TABLE I - Annual average of number of specimens $/ \mathrm{m}^{3}$ of $D$. nationalis

\begin{tabular}{crrrr} 
Cananéia & Pt I & Pt II & Pt III & Total \\
1958 & 3.92 & 6.30 & 44.90 & 55.12 \\
1959 & 35.14 & 28.91 & 69.01 & 133.06 \\
$\begin{array}{c}1960 \\
\text { Total }\end{array}$ & 24.40 & 22.41 & 15.57 & 62.38 \\
& 63.46 & 57.62 & 129.48 & 250.56 \\
\hline Santos & Pt I & & Pt III & \\
1960 & 6.28 & & 46.04 & 52.32 \\
\hline
\end{tabular}

The great swarms present in November and December were preceded by the lowest occurrences of the three years. It was noticed that this scarcity came just after the presence of swarms of salps. Fraser (1961) suggested that the salps tend to denude the water of phytoplankton and, therefore, the food supply of the zooplankton.

With regard to its preference for one or other water-type, the behaviour of the species was not clear. The occurrence of $D$. nationalis was definitely higher at Pt III off Santos where, the Shelf-Water predominated as mentioned earlier. However, the occurrence of this species was remarkably high off Cananéia were Coastal-Water predominated at all three points.
Genus: Doliotetta ss. (Garstang 1933)

Dolioletta gegenbauri Uljanin, 1884

This species was also recorded at about this latitude by the 'Terra Nova' and 'Meteor' Expeditions and, more extensively, by the 'Plankton' Expedition. The distribution of $D$. gegenbauri is one of the most widely-recorded species among the doliolids. In the present study, the most abundant form is the gonozooid, followed by the phorozooid, "old nurse" and oozooid. It was noticed that all of these presented a somewhat crumpled appearance which dit not occur as frequently with the $D$. nationalis. This is perhaps due to the very thin and delicate test of the species, as noted by Berrill (1950).

The oozooids and blastozooids measurements are given in Table II. It was not possible to determine the number of gill-slits in the blastozooid form because the lamella was frequently coiled and folded. In the oozooid, however, it was possible to observe a much-reduced lamella -4 or 5 slits - spit the specimens's crumpled appearance.

TABLE II - Average lenght of $D$. gegenbauri $\begin{array}{cc}\text { Total length } & \text { Endostyle length } \\ (\mathrm{mm}) & (\mathrm{mm})\end{array}$

$\begin{array}{lll}\text { Blastozooid } & 2.83 & 1.25\end{array}$

(Phorozooid \&

Gonozooid)

Oozooid

1.49

0.70

"Old nurse"

4.72

The oozooids are somewhat smaller than the blastozooids yet the "old nurse" are smaller than the figures given by Garstang $(l . c$. $)$ for specimens found at about this latitude: $18^{\circ} \mathrm{S} \cdot 23^{\circ} \mathrm{S}$ (South Atlantic, between Rio de Janeiro and Trindade Island). Such specimens presented a range between 6 and $18 \mathrm{~mm}$ for total length.

As recommended by Garstang (1933) and GodEaUX (1957), detailed observation was made on the muscle-bands and the ganglion and nerves of these "old nurse".

In Table III, the average measurements for muscle-bands as found by Garstang and the present specimens are compared.

TABLE III - Width of muscles as percentage of total muscle length in D. gegenbauri, "old nurses"

\begin{tabular}{l|c|c|c|c|c|c|c|c|c|c|c}
\hline & Number of & $\begin{array}{c}\text { Average } \\
\text { body } \\
\text { specimens } \\
(\mathrm{mm})\end{array}$ & \multicolumn{5}{|c|}{ Width of muscle as percentage of total muscle } \\
\cline { 4 - 10 } & 29 & 7.3 & 2.8 & 10.3 & 18.9 & 18.2 & 15.3 & 14.3 & 11.3 & 5.9 & 2.9 \\
\hline $\begin{array}{c}\text { Garstang's } \\
\text { specimens }\end{array}$ & 36 & 4.7 & 3.1 & 10.7 & 17.1 & 17.5 & 15.7 & 14.3 & 11.6 & 5.8 & 4.0 \\
\hline $\begin{array}{c}\text { Presente } \\
\text { specimens }\end{array}$ & & & $\mathrm{M}_{2}$ & $\mathrm{M}_{3}$ & $\mathrm{M}_{4}$ & $\mathrm{M}_{5}$ & $\mathrm{M}_{6}$ & $\mathrm{M}_{7}$ & $\mathrm{M}_{8}$ & $\mathrm{M}_{9}$ \\
\hline
\end{tabular}


Only $\mathrm{M}_{1}$ and $\mathrm{M}_{9}$ when compared with Garstang's figures show some discrepancy. This can be disregarded since these two muscles are so often damaged and contracted that their measures may be rather inaccurate. BARY (1960) on working the same analysis on "old nurses" from the New Zealand area, preferred to omit these two figures from his data. Garstang $(l . c$.$) suggested that due to the contracted$ state of the muscles - which act as sphincters - one can often measure only the thickness instead of the width.

The $\mathrm{M}_{3}$ and $\mathrm{M}_{4}$ are largest muscles, as might be expected, on $D$. gegenbauri's "old nurse". However, the slight predominance of width of $\mathrm{M}_{3}$ over $\mathrm{M}_{4}$ was not verified. This could be explained by smaller size of the present specimens, yet Garstang remarked that $\mathrm{M}_{3}$ and $\mathrm{M}_{4}$ remain approximately equal, up to a size of $6 \mathrm{~mm}$, above which $\mathrm{M}_{3}$ predominates.

Regarding the ganglion and its nerves, the same arrangement was observed in the oozooid and "old nurse". There are nine nerves, distributed as follows: from the anterior part of the ganglion a single nerve is originated which proceeds frontally while two other pairs are directed laterally. At the posterior, one pair begins towards the back of the animal. From each side, a single nerve takes a median lateral direction. This description agrees with that made by Godeaux (1957), of $D$. denticulatum and $D$. gegenbauri "old nurses". The otolith was always present in the specimens studied. As remarked by GaRstang $(l . c$.$) , the otolith usually drops away$ after death in genus such as Doliolina, but only rarely in D. gegenbauri; it was always present here.

Distribution - During the three-year survey, $D$. gegenbauri, like $D$. nationalis, showed a very irregular pattern of distribution. Table IV shows the average annual distribution for both Santos and Cananéia.

\begin{tabular}{|c|c|c|c|c|}
\hline Cananéia & Pt I & Pt II & Pt III & Total \\
\hline 1958 & 9.46 & 25.96 & 27.38 & 62.80 \\
\hline 1959 & 19.96 & 28.53 & 22.56 & 71.05 \\
\hline 1960 & 9.19 & 10.24 & 12.54 & 31.97 \\
\hline Total & 38.61 & 64.73 & 62.48 & 165.82 \\
\hline Santos & Pt I & & Pt III & Total \\
\hline 1960 & 14.75 & & 62.39 & 77.14 \\
\hline
\end{tabular}

The highest occurrence of both $D$. gegenbauri and D. nationalis was in 1959 . It seems that the latter showed a clear numerical predominance at the offshore stations. At Cananéia, D. nationalis predominated quantitatively over $D$. gegenbauri but, at Santos, D. gegenbauri showed a higher average. Number the numerical level of $D$. nationalis was still recorded however as being relatively high.
Conclusion on Doliolids - Fraser (1955) considered $D$. nationalis as an indicator of Lusitanian waters, and D. gegenbauri a Cosmopolitan Oceanic Species. FurNESTIN (1960) recorded greater abundance of $D$. nationalis at lower salinities $(35-36 \%$ oo $)$ and Токіока (1960) mentions a tendency of the species to increase coastalwards.

The present collection suggests that $D$. nationalis and $D$. gegenbauri are endemic species in the region studied since they were observed throughout the three-year period. However, since almost only the phorozooid forms of $D$. nationalis were caught, it may be supposed that only one phase of their life-history takes place in this region. The other forms probably occur outside the area.

During the countings of doliolids, the other main components of the samples were observed. It was noticed that if swarms of salps or blooms of diatoms were caught in winter (or, only occasionally in spring), the presence of doliolids was definitely reduced. The large numerical variation of this group could therefore be a function of selectivity factors introduced among the samples, although such factors could mask the effects of temperature, seasonal variation or water types.

Family SALPIDAE

Genus: Thalia Blumenbach, 1810

Thalia democratica Forskal, 1775

This very common salp in warm-water regions was the only species recorded in this area. Both forms, aggregate and solitary, were present. Their size varied considerably, ranging from 3 to $9 \mathrm{~mm}$ for total lenght. BARY (1960) studying this species in New Zealand waters gave 9.5 to $27 \mathrm{~mm}$ as length for aggregate forms and 4 to $16.5 \mathrm{~mm}$ for solitary ones. Their measurements included the test prolongations. Yount (1954) in the Pacific gave 4 to $9 \mathrm{~mm}$ for total length, not including test prolongations. Compared with BaRY $(l . c$.$) , the present$ specimens were somewhat smaller and agree more closely with Yount's data.

The number of blastozooids always exceeds that of oozooids. This could be expected since one oozooid budding from its stolon can give rise to hundreds of blastozooids, while a blastozooid produces only one oozooid. BRAConnot (1963) studying the annual cycle of this species also pointed out the numerical predominance of blastozooids over oozooids. In Figure 2, the quantitative occurrence of both forms is shown.

These populations of salps presented another interesting aspect when the salps started to appear in the region, the solitary forms were mature and showed chains of very young aggregates. In the subsequent sample, fifteen days later, the population was mainly composed of adult aggregate forms and the solitary ones then found were almost young embryos, still within the body of the blastozooids or were newly-hatched individuals. This suggests that a complete cycle had taken place in the meantime. Braconnot $(l . c$.$) reared T$. democratica in laboratory experiments and discovered that the period for liberation of the oozooid, its subsequent development 


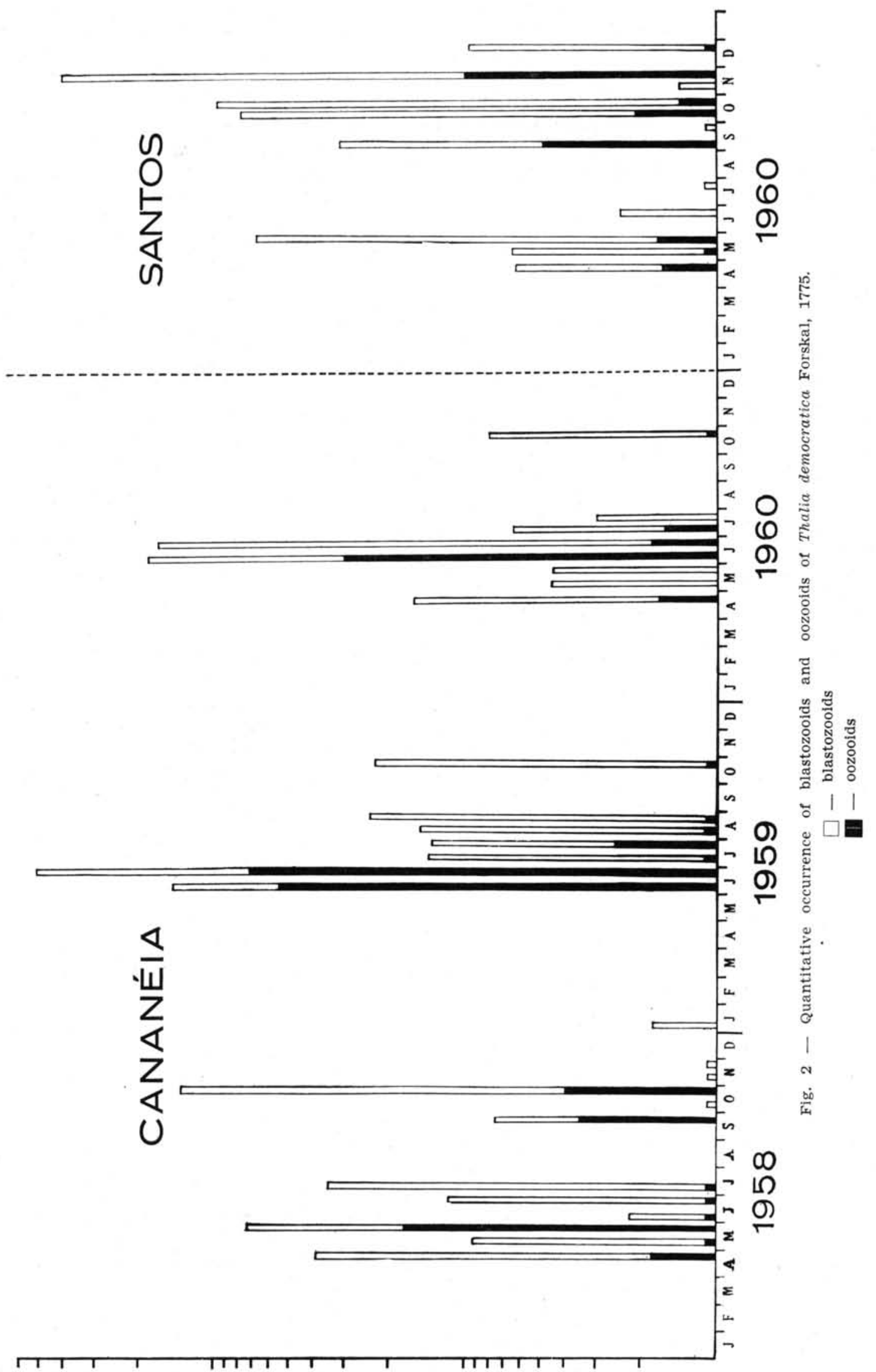


and production of one to three chains takes some 8-12 days. This could partly explain the aggregation in swarms which is always shown by this species.

Distribution - Unlike the doliolids, T. democratica did not appear frequently throughout the period of survey. At Cananéia and Santos, salps were not found (except for some few specimens on one occasion) between January and March. Towards the end of April, the first swarms appeared and remained in the area until July (August in 1959). In September and October they appeared again in smaller numbers at Cananéia but, at Santos, were collected in great abundance.

SEwEll (1926) associated the presence of $T$. democratica to periodical variations in salinity, and several authors (THOMPSON 1948; BERNARD 1958; BARY 1960) emphasized the effects of temperature. In the present survey, the water temperature registered at the time of the larger occurrences ranged from $19.22^{\circ} \mathrm{C}$ (April-July) or up to $23^{\circ} \mathrm{C}$ (September-October). Higher temperature, $25-28^{\circ} \mathrm{C}$ were recorded in those months when the species was totally absent. T. democratica occurred, therefore, in this region in the period of lowest temperature. This agrees with BERNARD (1958) who noticed a maximal occurrence when the temperature was below $20^{\circ} \mathrm{C}$.

Regarding vertical distribution, the species was found throughout the column, $0.40 \mathrm{~m}$ of water, with numerical concentration on the surface. At Cananéia, there was no local preference. At Santos, however, the presence at $\mathrm{Pt}$ I was insignificant, while at $\mathrm{Pt}$ III the salps were very abundant.

Conclusion on Thalia democratica - The presence of salps could be explained by the penetration of oceanic waters during the colder months. EMilsson (personal communication, 1964), study. ing hydrographical conditions off the São Paulo coast observed that due to the weakening of the Prazil Current here, in the winter, an invasion of oceanic waters towards the coast takes place. This fact could explain the occurrence of salps in this region. As GODEAUx remarked (1962, p. 30), "Les Tuniciers pélagiques sont des animaux du large; leur présence en un endroit déterminé indique l'exis. tence des courants les amenants de la mer libre".

The conditions prevailing in this region could favour the formation of dense swarms, as suggested by VANNUCCI (1962, p. 4). "Presumably the small degree of variation of total radiation throughout the year, associated to continuously high water temperature promotes a quick rate of reproduction and tends to cause the formation of local patches..."

\section{ACKNOWLEDGEMENTS}

Thanks are due to Dr. Marta VAnnuccI who suggested the study of this group; to Dr. LiLIanA Forneris and Miss M. S. DE Almeida Prado for their kind advice and helpful suggestions; to Mrs. Marion Lupu for assistance with the text and to my colleagues who, in many ways, have contributed to the ellaboration of this paper. I am indebted to FAPESP for partially supporting this research.

\section{R ES U M O}

O presente trabalho apresenta um estudo dos Thaliacea coletados ao largo de Santos e Cananéia em 1958, 1959, e 1960. Foram estudados aspectos morfológicos e ecológicos das espécies coletadas: Doliolum nationalis, Dolioletta gegenbauri e Thatia democratica.

Os doliolidos parecem ser endêmicos nesta área, ocorrendo durante todo o período de coletas. As salpas ocorrem só ocasionalmente em densos "cardumes", sugerindo que esta espécie introduzida nesta área por águas oceânicas.

\section{R E F E R E N C E S}

Almeida Prado, M. S. de

Distribution and annual occurrence of Chaetognatha off Cananéia and Santos coast (São Paulo, Brazil). (Under press).

BARY, B. M.

1960. Notes on ecology, distribution and systematics of pelagic tunicates from New Zealand. Pacif. Sci., vol. 14, n. ${ }^{\circ}$, p. 101-121.

BERNARD, M

1958. Systématique et distribution saisonnière des tuniciers pélagiques d'Alger. Rapp. P.-v. Réun. Commn int. Explor. scient. Mer Méditerr., n.s., vol. 14, p. 211-231, 15 text-figs.

Berrill, N. J.

1950. The Tunicata with an account of the British species. London, Ray Soc., p. 268-322, text-figs. 97-120.

BJöRNBERG, T. K. S.

1963. On the marine free-living copepods off Brazil. Bolm Inst. oceanogr., vol. 13, n. ${ }^{\circ} 1$, p. 3-142, 51 figs.

Borgert, A. H. C.

1894. Die Thaliacea der Plankton-Expedition. C. Vertheilung der Doliolen. Ergebn. Plankton-Exped. Humboldt-Stift., vol. 2 , E a c, 68 p. est. 5-8.

BraconNot, J. C.

1963. Étude du cycle annuel des salpes et dolioles en rade de Villefranche-sur-Mer. J. Cons. perm. int. Explor. Mer, vol. 28, n. ${ }^{\circ} 1$, p. 21-36, 6 text-figs.

EMílsSon, I

1961. The shelf and coastal waters off southern Brazil. Bolm Inst. oceanogr., vol. 11 n. $^{\circ}$ 2, p. $101-112,3$ text-figs.

ForNeris, L

1965. Appendicularian species groups and southern Brazil water masses. Bolm Inst. oceanogr., vol 14, fasc. único, p. 53-114.

Fraser, J. H.

1947a. Thaliacea I. Family Salpidae. Fich. Ident. Zooplancton, n. $9,4 \mathrm{p}$.

1947b. Thaliacea II. Family Doliolidae. Fich. Ident. Zooplancton, n. ${ }^{\circ} 10,4$ p.

1955. The plankton of the waters approaching the British Isles in 1953. Mar. Res., n. 1,12 p. 
1961. The oceanic and bathypelagic plankton of the North East Atlantic. Mar. Res., n. ${ }^{\circ} 4,48 \mathrm{p}$.

Furnestin, M. L.

1960. Zooplancton du Golfe du Lion et de la côte orientale de Corse. Revue Trav. Inst. Pêch. marit., vol. $24, \mathrm{n}^{\circ} 2$, p. 153-252.

Garstang, W.

1933. Report on the Tunicata. Part. I. Doliolida. Nat. Hist. Rep. Br. Antarct. Terra Nova Exped., Zool., vol. 4, n. ${ }^{\circ} 6$,

GodeAux, J. p. $195-251,8$ text-figs.

1957.

Contribution à la connaissance des thaliacés (Pyrosome et Doliolum). Annls Soc. r. zool. Belg., vol. 88, p. 1-285, 103 text-figs.

1961. L'oozoide de Doliolum nationalis Borgert. Bull. Soc. r. Sci. Liége, vol. 30, n. $1 / 2$, p. $5-10$.

1962. Tuniciers pélagiques. Expéd. océanogr. belge Eaux afr. Atlant. sud, vol. 3, n. 7,32 p. map 1,5 text-figs.

KRUGER, $\mathrm{H}$.

1939.

Die Thaliaceen der 'Meteor'-Expedition. Wiss. Ergebn. dt. Exped. 'Meteor' 192527, vol. 13, n. $^{\circ} 2$, p. 111-152.

Metcalf, M. M.

1918. The Salpidae, a taxonomic study. Bull. U. S. natn. Mus., 100 , vol. 2, part 2, 193 p., 150 text-figs., 14 est.

Russell, F. S. \& Hastings, A. B.

1933.

On the occurrence of pelagic tunicates (Thaliacea) in the waters of the English Channel off Plymouth. J. mar. biol. Ass. U. K., vol. 18 , n. $^{\circ} 2$, p. 635640.
SEWELl, R. B. S.

1926. The salps of Indian seas. Rec. Indian Mus., vol. 28 , p. $65-126,43$ text-figs.

TERRY, R. M.

1961. Investigation of inner continental shelf waters off lower Chesapeake Bay, part III. The phorozoid stage of the tunicate Doliolum nationalis. Chesapeake, Sci., vol. 2 , n. $1 / 2$, p. $60-64,3$ figs.

THompsoN, H.

1948. Pelagic tunicates of Australia. Melbourne, Commonw. Coun. Sci. Industr. Res. Australia, 196 p. +75 p. ilus., 10 text-figs.

ToKIoKA, K.

1960.

Studies on the distribution of appendicularians and some thaliaceans of the North Pacific, with some morphological notes. Publs Seto mar. biol. Lab., vol. 8, n. $^{\circ} 2$, p. $351-443,16$ text-figs., 32 tabl.

VANNUCCI, M.

1962. Preliminary results on the study of the zooplankton standing stock off south Brazilian coast at $25^{\circ}$ Lat. S. Contrções Inst. oceanogr. S Paulo, sér. Ocean. biol., n. ${ }^{\circ} 3$, p. 1-28, figs. tabs.

1963. On the ecology of Brazilian Medusae at $25^{\circ}$ lat. S. Bolm Inst. oceanogr., vol. 13, n. ${ }^{\circ} 1$, p. $143-184$.

YouNT, J. L.

1954. The taxonomy of the Salpidae (Tunicata) of the central Pacific Ocean. Pacif. Sci., vol. 8, n. ${ }^{\circ}$ 3, p. 276-330, 30 text-figs.

\section{PLATE I}

Explanation of the figures

A - Doliolum nationalis Borgert 1893, phorozooid.

B - Doliolum nationalis Borgert 1893, gonozooid.

C - Dolioletta gegenbauri Uljanin 1884, phorozooid.

D - Dolioletta gegenbauri Uljanin 1884, gonozooid. 
PLATE I

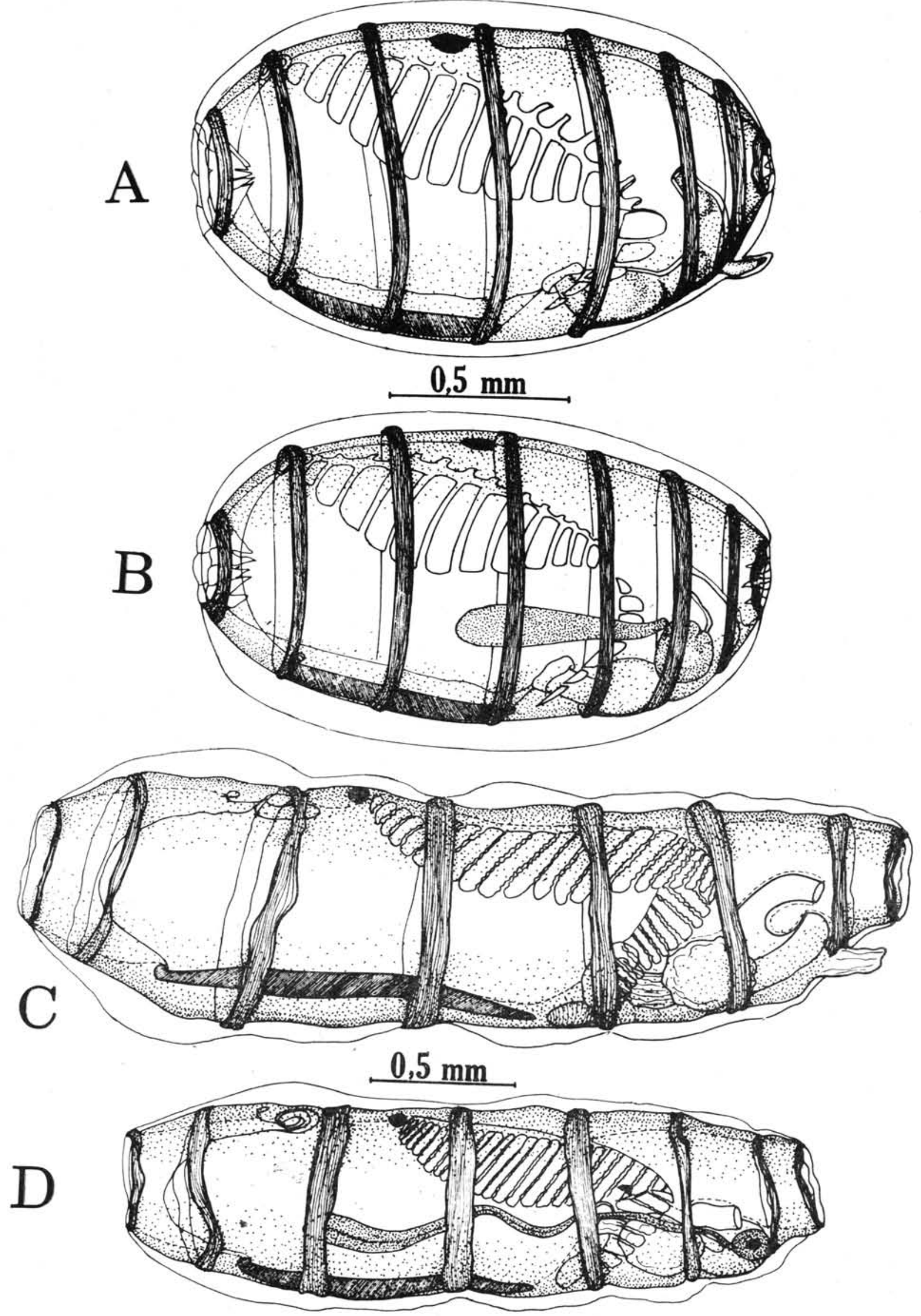




\section{PLATE II}

Explanation of the figures

E - Dolioletta gegenbauri Uljanin 1884, oozooid.

F - Dolioletta gegenbauri Uljanin 1884, "old nurse".

G - Thalia democratica Forskal, 1775, oozooid, solitary form.

H - Thalia democratica Forskal, 1775, blastozooid, aggregate form. 
PLATE II
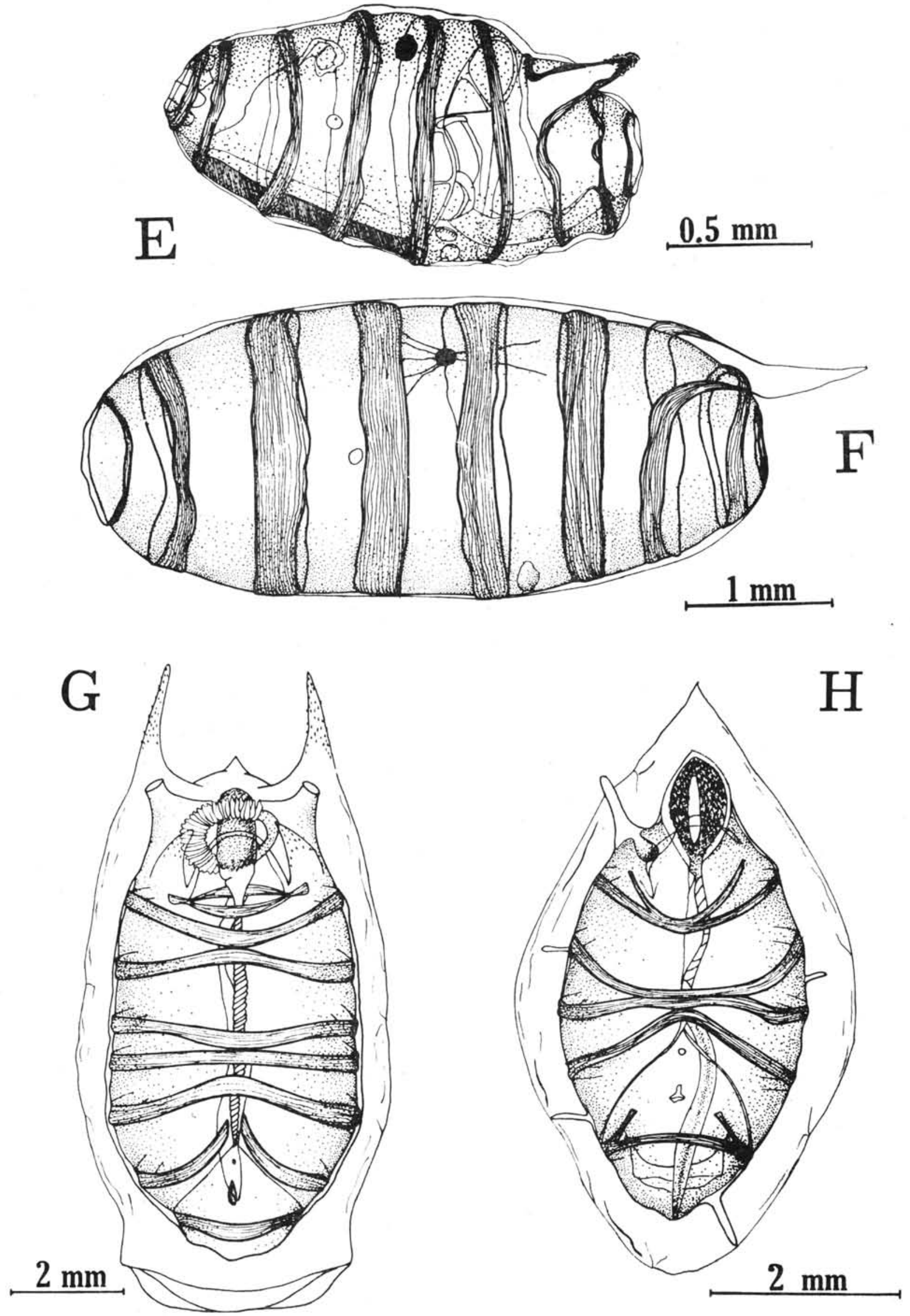